\title{
Adaptation policy and practice in densely populated glacier-fed river basins of South Asia: a systematic review
}

\author{
Ridhima Sud • Arabinda Mishra • \\ Navarun Varma $\cdot$ Suruchi Bhadwal
}

Received: 31 August 2013/ Accepted: 12 March 2014/Published online: 31 January 2015

(C) The Author(s) 2015. This article is published with open access at Springerlink.com

\begin{abstract}
Rivers are the cultural, social and economic backbone of South Asia, and therefore, the focus of public, political and scientific debate. Himalayan glaciers are the source of numerous large Asian river systems, which support rich ecosystems and irrigate millions of hectares of fields, thereby supporting about a billion people who live in their catchments. Impacts of climate change in river systems are likely to have considerable social, economic, ecological and political implications. This paper reviews literature for three major glacier-fed river systems of South Asia-Brahmaputra, Ganga and Indus - to understand governance mechanisms for climate adaptation in the region. A systematic review methodology is applied to examine adaptation responses in the riparian countries of these Himalayan river basins in three different levels-policy objectives, institutions and practice. Using the "fit for purpose" governance framework, we try to examine how far or near is the region for operationalizing principles of adaptive governance.
\end{abstract}

Keywords River basins - Glacier fed - Systematic review methodology $\cdot$ Climate policy $\cdot$ Adaptive governance

\section{Introduction}

Glacier and snow-pack-dependent river basins situated in the Himalayan region come under the climate change "hotspot" category according to the Intergovernmental

Electronic supplementary material The online version of this article (doi:10.1007/s10113-014-0711-z) contains supplementary material, which is available to authorized users.

R. Sud $\cdot$ A. Mishra $(\bowtie) \cdot$ N. Varma $\cdot$ S. Bhadwal

The Energy and Resources Institute (TERI), IHC Complex,

Lodhi Road, New Delhi 110 003, India

e-mail: amishra@teri.res.in
Panel on Climate Change (Cruz et al. 2007). Reduced water flows in the major Himalayan river systems are expected to result in adverse impacts on agricultural production, hydro-energy generation and physical infrastructure (Vass et al. 2009; Xu et al. 2009; Mirza 2011; Immerzeel et al. 2012; Rupper et al. 2012), which will have significant welfare implications for the entire South Asia region. Climate change is also associated with the risk of flooding, and in the South Asian countries of Bangladesh, India, Nepal and Pakistan, the frequency and magnitude of disastrous floods is observed to have already increased (Atta-ur and Khan 2011; Gaurav et al. 2011; Mirza 2011; Moors et al. 2011; Tariq and van de Giesen 2012). Similarly, the frequency of glacial lake outburst floods (GLOFs) in the Himalayas is reported to have risen in recent decades (Dahal and Hagelman 2011). Thus, although the distinction between strictly climate-induced events and anthropogenic influences that aggravate the severity of natural hazards is still unclear, there is enough evidence to suggest the increased vulnerability of the region.

The three major Himalayan river basins-Brahmaputra, Ganges and Indus - that are the focus of this paper are spread over six countries of South Asia (Afghanistan, Bangladesh, Bhutan, India, Nepal and Pakistan). The basins of the Indus and Ganges rivers together cover 2.20 million $\mathrm{km}^{2}$ and are inhabited by over a billion people (Sharma et al. 2010); the lower Brahmaputra basin is home to nearly 300 million people (Kamal-Heikman et al. 2007). India's National Ganga River Basin Authority (NGRBA) reports that more than half of the poor in the country live on the main stem of the Ganges and that by 2,050, this population is expected to rise to approximately 720 million from an estimated 500 million in 2001 (Hosterman et al. 2012).

Given the large geographical spread of the three river basins along with the huge number of poor people living in 
the region, adaptation to the anticipated adverse impacts of climate change is soon expected to feature dominantly in the mainstream policy discourse of the concerned countries. There is already recognition of the threat by the national governments, as evident from several initiatives and policy measures adopted in the region. As part of their reporting obligations to the United Nations Framework Convention on Climate Change (UNFCCC), in the form of their National Communications (NCs) and National Adaptation Programmes of Action (NAPAs), for example, South Asian countries have reviewed developmental objectives and focused on optimizing outcomes of developmental activities that would also deliver climate change co-benefits. The emphasis is on the most advantageous utilization of available human, technical and infrastructural resources to reduce vulnerabilities and build adaptive capacity of people and ecosystems.

This paper is an attempt to inform the above discourse by presenting a comprehensive assessment of the state-ofknowledge as well as state-of-affairs with respect to climate change adaptation policy and practice in the South Asia region. A systematic review methodology is adopted for the purpose, and the findings of the study are expected to assist in the design of adaptation interventions that aim to build resilience of vulnerable populations and their livelihoods, which is the focus of this special edition (De Souza et al. 2015) and also identify priorities for collaborative adaptation research in the region.

\section{Materials and methods}

Systematic review methodology

Systematic review methodology is emerging as a promising tool for synthesis and rigorous characterization of vast and emerging body of knowledge for identification of research gaps in an "unobtrusive" way (Ford and Pearce
2010; Berrang-Ford et al. 2014). Although a relatively new methodology in the field of climate science, several advantages over the standard review methods are cited, the most significant being the scope for conducting both quantitative and qualitative analysis of trends in the literature while providing essential details on the review procedures applied, which can help in validating interpretation and replicating the study to test interpretation (BerrangFord et al. 2011; Ford et al. 2011; Biesbroek et al. 2013). Greater transparency in syntheses of knowledge is expected to help the public discourse move from the scientific process to public policy actions by clarifying the evidential basis for climate change science (Ford and Pearce 2010; Lesnikowski et al. 2011, 2013; Petticrew and McCartney 2011).

This study is based on information generated from the systematic mapping of peer-reviewed published journal papers available via ISI Web of Knowledge and a limited selection of grey literature documents, primarily government reports. The review focuses on literature published post 2006 and is limited to publications in English. The year 2006 is identified as the base year for the review to build upon the information generated post IPCC Fourth Assessment Report (IPCC 2007) which covers information till 2006.

\section{Searches for peer-reviewed literature}

The ISI Web of Knowledge database was searched to extract relevant articles. The keywords (Table 1) were identified by making reference to flagship reports on climate change (e.g. IPCC 2007) and consultations with experts who helped refine the choice of keywords used for the searches. Using these keywords, 192 research articles were identified and the title and abstract of the articles reviewed applying the inclusion and exclusion criteria mentioned in Table 2. In case of doubt, the full text of the articles was screened to ensure relevance. Finally, 33 peer-

Table 1 Search terms used in Web of knowledge

S. no Choice of keywords

1 Topic = ("climat*" OR "global warming” OR "climate hazard" OR "extreme weather" OR "flood" OR "drought" OR "glacier" OR "temperature" OR "precipitation" OR "disaster") AND Topic = ("adapt" OR "vulnerab*" OR "cop*" OR "capacity" OR

"resilience” OR "policy” OR "practice” OR “case stud*” OR “disaster reduc*” OR "risk management” OR "response”) AND Topic = ("government" OR "nation*" OR "transboundary" OR "policy" OR "program" OR "scheme" OR "socioeconomic" OR "population" OR "communit*" OR "farmer" OR "livelihood" OR "freshwater" OR "watershed" Or "water management" OR "food" OR "employment" OR "data" OR “irrigation" OR “yield” OR “institution” OR "development" OR "cooperation” OR "conflict" OR "security") AND Topic = ("South Asia" OR "India" OR "Afghanistan" OR "bhutan" OR "Nepal” OR "Pakistan" OR "Bangladesh" OR "Himalayas") AND Topic = ("river" OR "river basin" OR "Ganga" OR "Ganges" OR "Indus" OR "Brahmaputra")

2 Topic = ("climat*" OR "global warming" OR "climate hazard" OR "flood" OR "drought" OR "glacier" OR "precipitation" OR "disaster") AND Topic = ("gang*" OR "indus" OR "Brahmaputra”) AND Topic = ("integrat*” OR "mainstream" OR "policy" OR “practice” OR “development” OR "governance”) 
Table 2 Inclusion and exclusion criteria

\begin{tabular}{ll}
\hline Included & Excluded \\
\hline Literature published between 2006 and 4 May 2013 & Literature published before 2006 and after 4 May 2013 \\
Indexed in the ISI web of knowledge & Not available in ISI web of knowledge \\
Findings relevant to the geographical area being examined & Regions beyond the scope of this study \\
Policy and practice relevant findings & Scientific assessments, model validation \\
Content relevant to the research & Irrelevant content \\
Reviews and articles & Proceedings paper and editorial material \\
\hline
\end{tabular}

reviewed articles were extracted for detailed review and analysis as meeting the inclusion criteria.

\section{Searches for grey literature}

Acknowledging that all knowledge related to policy and practice may not be in the peer-reviewed domain (Lesnikowski et al. 2011, 2013) and recognizing the methodological constraints in use of grey literature in systematic review (Ford et al. 2011), a limited selection of "grey" literature documents (documents that do not pass through the scientific peer-reviewed system) relevant to the study were identified. These are primarily government reports on climate change and country submissions to the UNFCCC, as these follow extensive multi-level consultative processes (proxy for a peer-reviewed process) (Lesnikowski et al. 2011, 2013).

Adaptive governance and the analytical framework

The analytical framework of the present study is drawn from the "adaptive governance" paradigm which is well suited for resource governance given the challenge of climate change (Rijke et al. 2012). The adaptive governance paradigm seeks to learn from diverse knowledge systems and experience, networking among various actors to facilitate social learning of novel solutions and leadership to navigate change in social processes (Folke et al. 2005). It recognizes systems thinking as a methodology for management and seeks stakeholder participation in every level of policy making for robust understanding of natural and social risks and feedbacks (Pahl-Wostl 2009).

Adaptive governance has the potential of guiding planning processes which can produce strategies which are not only robust in design but also socially acceptable. Most of the literature on this approach offers either the need for adaptive governance or identify factors influencing its emergence. However, Rijke et al. (2012) offer an operational framework, which has identification of purpose, mapping of the context and evaluation of the governance outcomes as three key steps for achieving adaptive governance. The participation of stakeholders takes a central role in each step, and hence, their outcome depends on the mix of stakeholders' value system and interests.

In this study, we link the three steps of Rijke et al. (2012) to three levels of governance, essentially, policy objectives, institutions and practice. Policy objectives define the desired goals for a society. Expert judgement has guided us to assess national climate policy objectives using the following five normative criteria:

- Distinction of climate change as additional stressorVariability in climate system becomes additional to the existing risks posed by nature and society. It is a longterm phenomenon and can influence every aspect of provisioning society; hence, it is crucial to identify its role as an additional stressor to existing developmental challenges.

- Mainstreaming climate change into developmentDevelopment has been a key priority in global south. But the climate change risk challenges the sustainability of development initiatives hence incorporating climate risks in the planning phase of such initiatives becomes a key factor.

- Influence of climate science in scale and scope in climate action - It is the guidance of climate science that differentiates climate change planning from any development planning. But there is always a limitation of precision of climate models and coupling of socialecological factors that influences decision and action; hence, the degree to which climate science can guide is important.

- Identification of institutional framework for climate action-Climate action will require cross-sectoral activity for e.g. issues of linkages of energy, water and agriculture. But the governance mechanisms in global south is yet to come out of a legacy of reductionist structures that have been framing rules for resource utilization and access; hence, identification of institutional frameworks for novel activities becomes important.

- Integration of capacity building in policy goal-There is a need to enhance capacity in research and development for climate science to reduce uncertainty, but 
equally important is the capacity to support integrated approaches and learning within decision making.

The second level of governance has institutions, which are a means to achieve policy objectives. The mapping of the institutional landscape is done in terms of function and scale of operation of the institutions that are specifically mandated to address the climate policy objectives. Finally, in the practice landscape, we examine the diversity of adaptation responses and seek to identify the key influencing factors on policy outcomes in the study region.

\section{Results}

Majority of the published studies on adaptation in the major Himalayan river basins are focused on the Ganges river basin and identify flooding as the principal hazard

The number of scientific publications on adaptation in the three major Himalayan river basins is observed to have increased significantly in recent years (2011 and 2012)

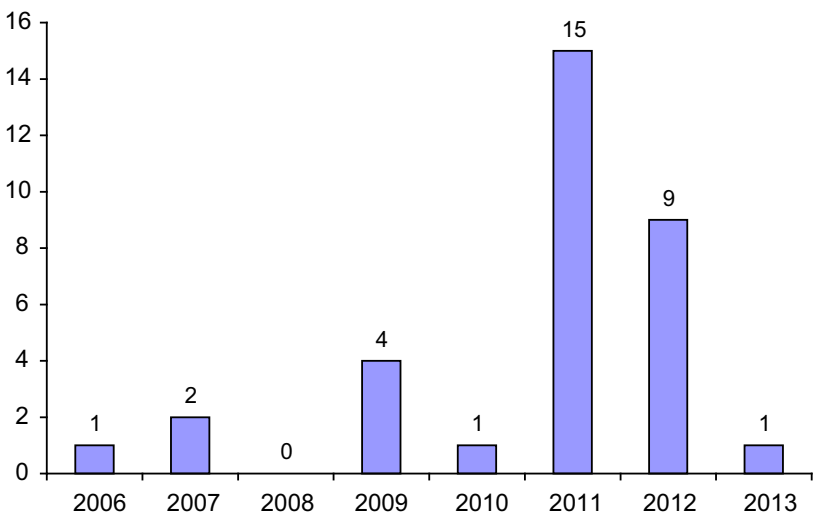

Fig. 1 Year-wise distribution of research papers (data till 4th May 2013) although there is no clear trend over the entire review period (Fig. 1).

Table 3 presents a basin-wise listing of the studies reviewed, and clearly the majority of the papers (approx. $27 \%$ ) have concentrated on the Ganges river basin. An analysis of the papers shortlisted for this study identify flooding as the principal hazard in these river basins (52\%), which is likely to get exacerbated in the light of climate change. This includes studies with a direct reference to floods (Chowdhury and Ward 2007; Osti and Egashira 2009; Atta-ur and Khan 2011; Barua and van Ast 2011; Dahal and Hagelman 2011; Gaurav et al. 2011; Karki et al. 2011; Mirza 2011; Chaliha et al. 2012; Jain et al. 2012; Shah et al. 2012; Tariq and van de Giesen 2012; Alfieri et al. 2013) as well as those with an indirect reference (Xu et al. 2009; Bocchiola et al. 2011; Kreutzmann 2011; Rupper et al. 2012).Other key vulnerability factors include high population density in the river basins, agriculture-based economy, unplanned development and human encroachments over floodplains, deforestation and the bio-physical parameters. The safety of hydroelectric power plants and infrastructure is a major concern in the light of GLOF events particularly as hydroelectric power is a major economic export for Bhutan (Rupper et al. 2012) and since India is planning a number of hydroelectric projects in the Himalayas (Jain et al. 2012).

Adaptation interventions reported in the published literature are categorized under planning and decision making, research, awareness and capacity building, and provisioning of infrastructure and technical resources

As evident from Fig. 2, majority (73\%) of the papers examined emphasize the need for and provide specific guidance on ways for proper planning and decision making in the context of climate change (Chowdhury and Ward 2007; Mustafa 2007; Osti and Egashira 2009; Pittock 2009; Vass et al. 2009; Xu et al. 2009; Lebel et al. 2010; Atta-ur

Table 3 Basin-wise list of studies from peer-reviewed literature

\begin{tabular}{ll}
\hline Basin focus & References \\
\hline Ganges (9) & Osti and Egashira 2009, Vass et al. 2009, Dahal and Hagelman 2011, Hosterman et al. 2012, \\
& Moors et al. 2011, Pandey et al. 2011, Immerzeel et al. 2012, Manandhar et al. 2012, Jain et al. 2012 \\
Brahmaputra (4) & Chaliha et al. 2012, Gain et al. 2012, Rupper et al. 2012, Shah et al. 2012 \\
Indus (8) & Fowler and Archer 2006, Mustafa 2007, Atta-ur and Khan 2011, Bocchiola et al. 2011, \\
& Gaurav et al. 2011, Karki et al. 2011, Kreutzmann 2011, Tariq and van de Giesen 2012 \\
Ganges-Brahmaputra (3) & Chowdhury and Ward 2007, Barua and van Ast 2011, Mirza 2011 \\
Ganges-Brahmaputra-Indus (3) & Xu et al. 2009, Lebel et al. 2010, Nandargi and Dhar 2011 \\
General (6) & Pittock 2009, Perveen and James 2011, Pittock 2011, Saleth 2011, Viviroli et al. 2011, Alfieri et al. 2013 \\
\hline
\end{tabular}

Studies specific to Nepal are placed under Ganges river basin; studies specific to Bhutan are placed under Brahmaputra river basin; articles placed in the "General" category are not specific to any particular river basin but have relevance for the study 
and Khan 2011; Gaurav et al. 2011; Karki et al. 2011; Kreutzmann 2011; Mirza 2011; Moors et al. 2011; Pandey et al. 2011; Perveen and James 2011; Pittock 2011; Saleth 2011; Hosterman et al. 2012; Manandhar et al. 2012; Gain et al. 2012; Tariq and van de Giesen 2012; Barua and van Ast 2011; Chaliha et al. 2012; Alfieri et al. 2013). These include developing flood forecasting and early warning capabilities, improved dialogue and collaboration between actors and sectors, better institutional coordination and transparent systems for monitoring and evaluation. The need for good governance, at all scales, with a greater role for local actors, strengthening regional cooperation and strengthening water management institutions have been repeatedly emphasized in the literature.

Strengthening research efforts is identified as a priority by $55 \%$ of the papers reviewed (Fowler and Archer 2006; Chowdhury and Ward 2007; Mustafa 2007; Xu et al. 2009; Bocchiola et al. 2011; Gaurav et al. 2011; Karki et al. 2011; Nandargi and Dhar 2011; Perveen and James 2011; Viviroli et al. 2011; Chaliha et al. 2012; Gain et al. 2012; Hosterman et al. 2012; Immerzeel et al. 2012; Jain et al. 2012; Rupper et al. 2012; Shah et al. 2012; Alfieri et al. 2013). These are primarily for improving capabilities for probabilistic forecasting and projections for future hydrological behaviour. Model simulation and parameterizations studies have been recommended for reducing uncertainties. Developing long-term research programmes, undertaking

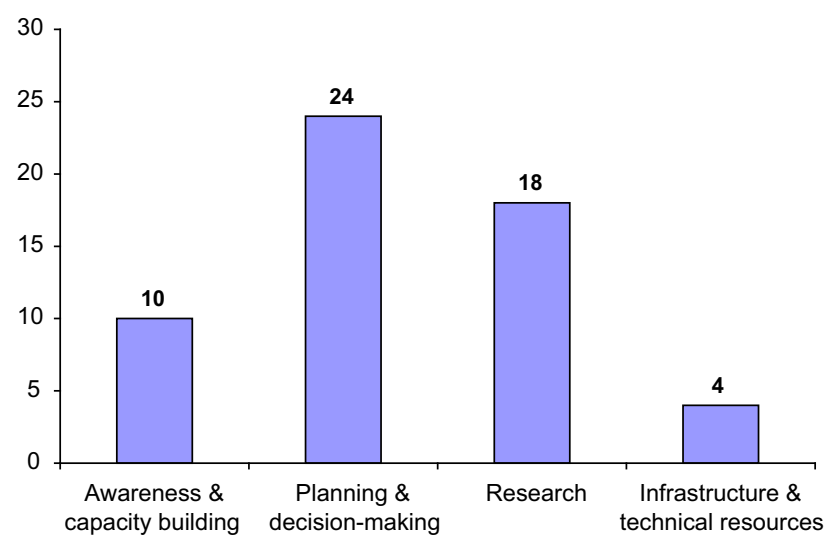

Fig. 2 Priorities identified for adaptation policy (from peer-reviewed literature)

Table 4 Cross-country comparison of climate policy objectives in South Asia

$P$ present, $A$ absent, $U$ unclear detailed studies at the regional as well as local level and generating a consolidated knowledge base areas are among the priority areas that have been identified.

Approximately $30 \%$ of the papers identify gaps in the levels of awareness and capacities of stakeholders, particularly local communities, to perceive climate risks and respond to the challenge (Chowdhury and Ward 2007; Lebel et al. 2010; Atta-ur and Khan 2011; Barua and van Ast 2011; Dahal and Hagelman 2011; Karki et al. 2011; Moors et al. 2011; Gain et al. 2012; Manandhar et al. 2012; Shah et al. 2012). Only $12 \%$ highlight specific infrastructural and technical resources required to aid in decision making (Atta-ur and Khan 2011; Gaurav et al. 2011; Viviroli et al. 2011; Jain et al. 2012). These include adopting structural measures for flood control, land use zoning, GIS-based interactive maps for spatial planning, river basin-scale flood risks maps and improved observation networks.

Ambiguity in climate policy objectives exists in varying degree among South Asian countries

Table 4 (based on information presented in supplementary material) brings out the diversity in climate policy objectives among the South Asian countries. For instance, while both Bangladesh and India have national climate policies that are complete in terms of goal setting (as per our five criteria), the others have built-in ambiguities/deficits in their policy purpose which may lead to challenges for their operationalization.

There is a common emphasis in the national-level climate policy objectives on livelihood security

The national-level climate policy documents reviewed for this study have a commonality in their aim to build the adaptive capacity of people by means of providing livelihood security in the face of climate change risks. For instance, the Climate Change Policy, 2011 of Government of Nepal aims to build resilience of local communities by enhancing capacities for efficient management of natural resource base and use of climate-friendly technologies. Due emphasis is also given to ensuring peoples'

\begin{tabular}{|c|c|c|c|c|c|c|}
\hline \multirow{2}{*}{ objectives in South Asia } & \\
\hline & Afghanistan & A & A & A & A & A \\
\hline & Bangladesh & $\mathrm{P}$ & $\mathrm{P}$ & $\mathrm{P}$ & $\mathrm{P}$ & $\mathrm{P}$ \\
\hline & Bhutan & $\mathrm{A}$ & $\mathrm{P}$ & $\mathrm{P}$ & A & $\mathrm{P}$ \\
\hline & India & $\mathrm{P}$ & $\mathrm{P}$ & $\mathrm{P}$ & $\mathrm{P}$ & $\mathrm{P}$ \\
\hline & Nepal & $\mathrm{A}$ & $\mathrm{U}$ & $\mathrm{P}$ & $\mathrm{P}$ & $\mathrm{P}$ \\
\hline osent $A$ ahsent & Pakistan & $\mathrm{A}$ & $\mathrm{P}$ & $\mathrm{U}$ & $\mathrm{P}$ & $\mathrm{U}$ \\
\hline
\end{tabular}


participation, especially of poor marginalized indigenous communities, women, children and youth, in the implementation of climate adaptation and climate change-related programmes. Similarly, the 2012 National Climate Change Policy of Government of Pakistan gives particular attention to the needs of economically and socially vulnerable sectors of the economy for the success of climate-resilient development in the country. It recognizes climate change as a serious threat to poverty reduction efforts and emphasizes the need to integrate poverty-climate change nexus into economic policies and plans (MoCC 2012).

India's Second National Communication to UNFCCC (MoEF 2012) states that the country "has pursued aggressive strategies on forestry and coastal management, recognizing their ecological as well as livelihood significance" (p164). More relevant to the river basins context is the Draft Water Policy 2012 (MoWR 2012a), which recognizes the potential threat to livelihoods by climate change-induced variability of water resources. Further, for safeguarding livelihoods, the policy suggests adopting integrated farming systems and encourages non-agricultural developments.

Institutions reported in the reviewed literature are primarily focused on strategic knowledge generation and management

Table 5 presents a list of the institutions that find mention in the reviewed literature (both peer reviewed and grey) and have a specific relevance to our study of adaptation response in the three South Asia river basins. It is clear that there is not much functional diversity among the listed institutions, and the dominant focus across countries is strategic knowledge generation.

The institution-level focus on strategic knowledge generation and management can be illustrated through a few examples. In India, the National Ganga River Basin Authority (NGRBA) and Brahmaputra River Valley Authority (BRVA) have been restructured to overcome earlier deficiencies in their management systems; generation of strategic knowledge base is a priority in the restructured management plans (MoEF undated; MoWR 2012b). Along with a Ganga Knowledge Centre, the NGRBA suggests formulating City-level Citizen Monitoring Committees and Forums for carrying out social audits of the River Ganga. Similarly, in Pakistan, the Indus River System Authority (IRSA) identifies the need to develop a GIS/MIS Centre and Decision Support System to develop its analytical functioning capacity.

One of the eight priority areas in India's National Action Plan on Climate Change (NAPCC) is a National Mission on Strategic Knowledge on Climate Change. India also provides an example of coordinated approach to strategic knowledge generation in the context of climate change. The Indian Network for Climate Change Assessment (INCCA), a network-based programme that brings together over 120 knowledge institutions and over 220 scientists from across the country, was established by Government of India in 2009 to carry out integrated assessments of climate change impacts on a collaborative mode (MoEF 2010).

The need for policy reforms to deal with climate change is commonly reported by the South Asian countries in their submissions to the UNFCCC

The need for institutional reforms for tackling the climate change challenge is well acknowledged by the South Asian countries in their submissions to UNFCCC. Afghanistan highlights the need for improving legal, policy and implementing frameworks by developing new legislation related to natural resource management (NEPA 2009, 2013). The Water Act of Bhutan 2011 recognizes climate change as an additional stressor which cannot be addressed within the purview of the existing policy framework. Bhutan also iterates the need for establishing an independent Water Authority as per the Water Act (Government of Bhutan 2011). Pakistan's National Climate Change Policy 2012 suggests formulation and enforcement of river flood plain regulations and laws for addressing projected increase in the frequency and intensity of extreme climate events (MoCC 2012). Bangladesh seeks to build cross-country collaborations and develop regional action plans with a focus on key issues including water security (MoEF 2009).

NAPAs provide a roadmap to adaptation practice while identifying the key barriers at the national level

Most countries recognize the scale of analysis for water resource management to be at the river basin or watershed level, and the major projects proposed in the NAPAs of Afghanistan, Bhutan and Nepal are designed at this scale (NEC undated, 2009; NEPA 2009; MoE 2010; NEC 2011). Besides, a range of activities have been prioritized including GLOF Hazard Zoning, Early Warning Systems, flood prevention and management, and strengthening of the hydrological and meteorological networks (Table 6).

Adaptation projects in the river basins under study are mostly at the local scale, with an emphasis on disaster risk management, and having government as the executing agency

Figure 3 is illustrative of the diversity of adaptation projects in the region. Majority $(52 \%)$ of the projects are initiatives at the local scale, and the experiential learning is inadequately documented. One-third of the adaptation 


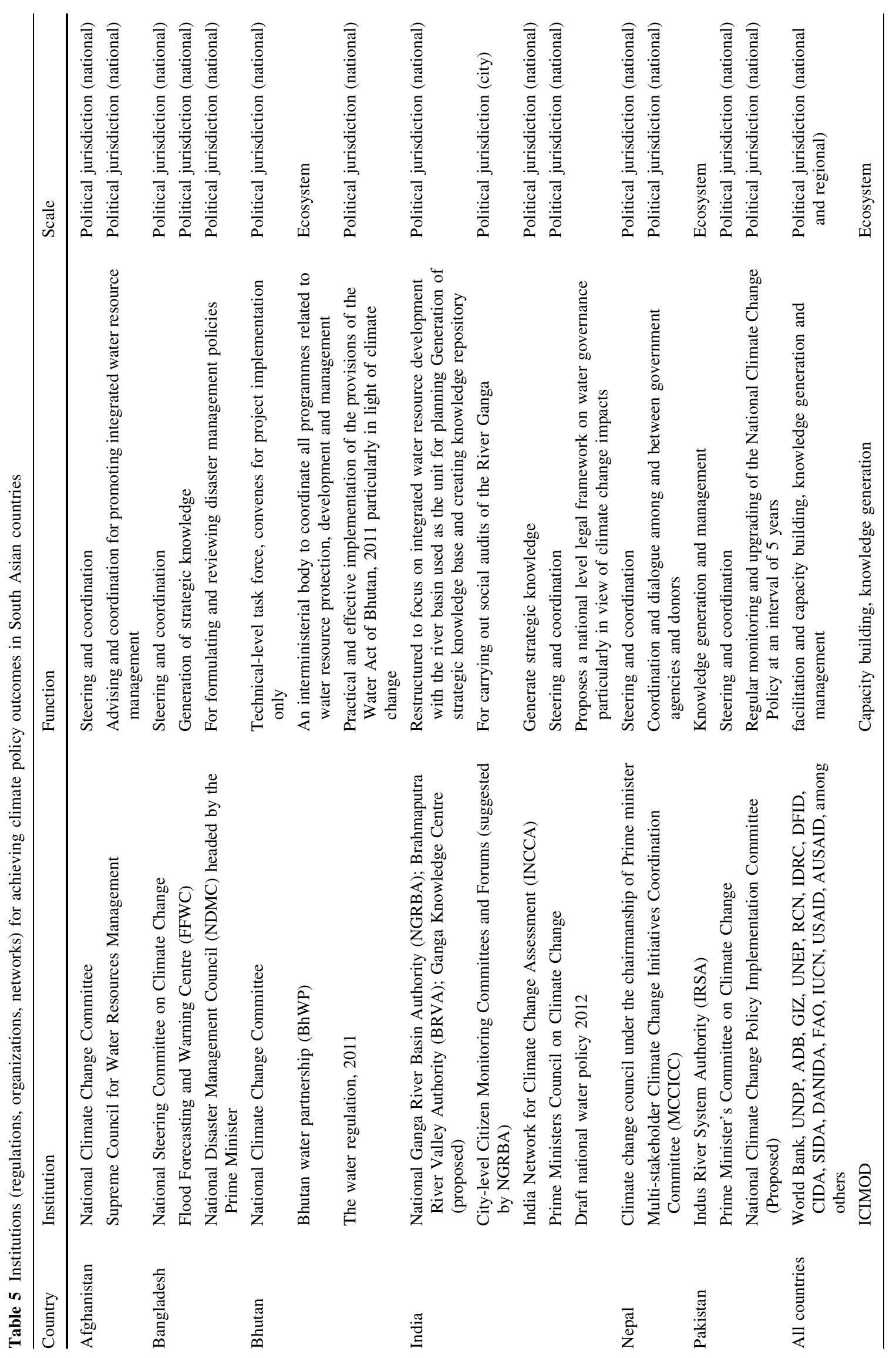


Table 6 National adaptation programmes of action (NAPAs)

\begin{tabular}{lll}
\hline Country & $\begin{array}{l}\text { Likely climate change impacts and key } \\
\text { adaptation needs }\end{array}$ & Prioritized activities \\
\hline
\end{tabular}

Afghanistan Floods due to untimely and heavy rainfall; flooding due to thawing of snow and ice; increasing temperatures

Bhutan

Increased GLOF events and flooding, increased rainfall in areas without proper drainage systems can cause soil instabilities leading to landslides and flash floods
Improved water management and use efficiency; Climate-related research and early warning system; Land and water management at the watershed level

Nepal Water resources and energy impacted by changes in hydrological cycle and climate-induced disasters increase in current frequency of hydrometeorological extreme events such as avalanches, floods and inundation

GLOF hazard zoning, early warning systems, flood protection of downstream industrial and agricultural area, landslide management and flood prevention
Integrated watershed management, promoting water management at river basin level at municipal areas, flood management, non-conventional irrigation systems in water stressed areas, monitoring GLOFs, early warning systems, hazard mapping, assessing disaster impacts, institutional and research capacity, managing existing hydrological and meteorological network
Challenges and barriers to implementing adaptation measures

Lack of capacity in terms of human resources; Low levels of awareness of the current and potential impacts of climate change; addressing both immediate development needs and climate change, limited analytical capability, especially for analysing climatic data to assess threats and potential impacts, and develop viable solutions, limited resources

Lack of national capacity in terms of human resources, integrating new concepts like adaptation to climate change effects into immediate infrastructural and development needs, limited analytical capability, especially for climate data to analyse threats, potential impacts and develop viable solutions, limited information and awareness about climate change

Weak governance (mainly due to extended political transition), limited delivery of development-related services, poor coverage of infrastructural facilities, high poverty rates, accumulated and additional costs to adaptation, lack of public awareness on climate change disasters and limited reach of early warning systems
Fig. 3 Percentage distribution of adaptation projects in terms of scale, focus and executing agency (see supplementary material)

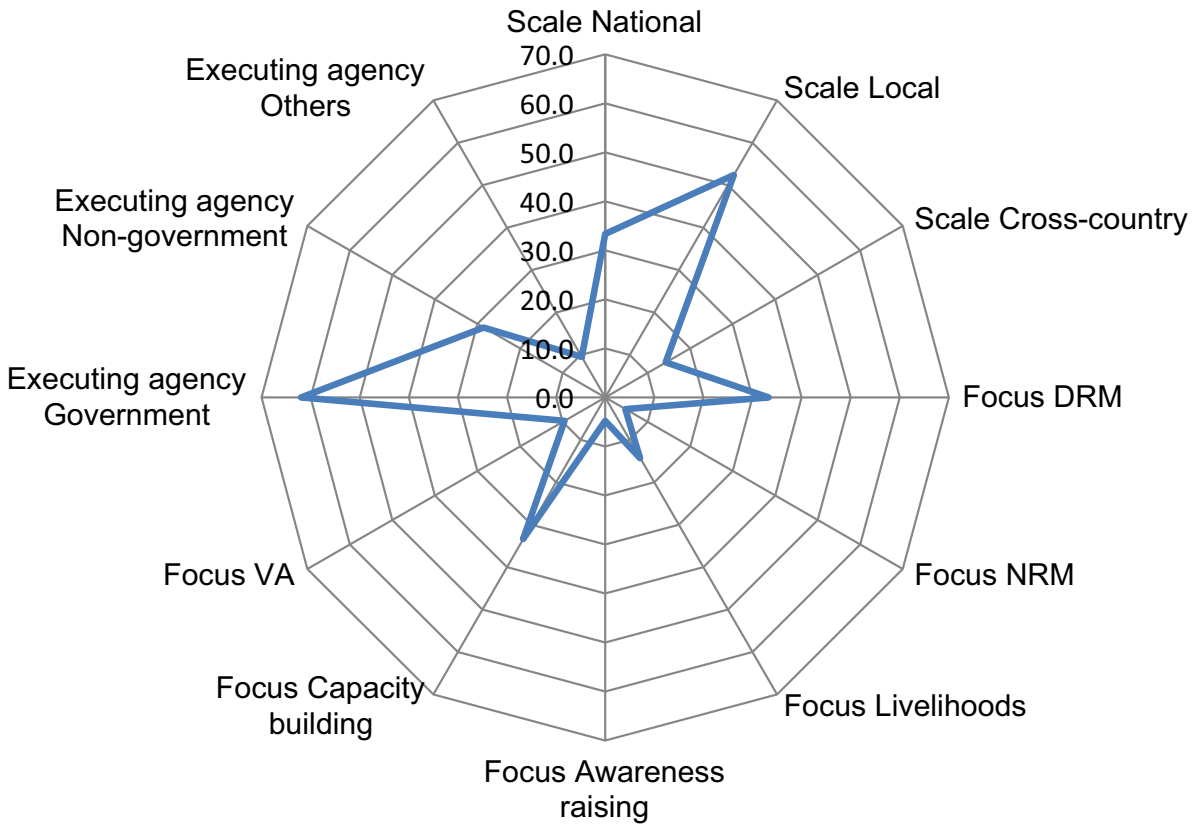


projects are at the national scale and only three out of the total twenty-one projects reviewed have a cross-country character. In terms of their focus, while a third of the projects are on disaster and risk management, another onethird of projects have capacity building as their core objective. This emphasis on disaster and risk management in adaptation projects in large river basins is also brought out in Ford et al's review in this special edition (Ford et al. 2014). Similarly, their finding for all "hotspots" about the overwhelming involvement of national governments in adaptation initiatives and absence of private sector is strongly corroborated in our review of adaptation projects in countries sharing the Himalayan river basins. We find $62 \%$ of the adaptation projects having national governments as the executing agency and not a single project with private sector involvement.

There are very few reports of cross-country adaptation projects/programmes

Among the South Asian riparian countries, enhanced regional collaboration for undertaking integrated scientific research, policy making and implementation of cross-country adaptation measures has been cited as a necessity (Xu et al. 2009; Mirza 2011; Viviroli et al. 2011). Dealing with major disasters (e.g. through international organizations) requires anticipation at the transnational level calling for substantial planning and information at different levels (Alfieri et al. 2013). Enhanced cooperation among the co-riparians will strengthen the knowledge and database required for better flood forecasting and issuance of early warnings which can considerably bring down the losses to life and economy.

As highlighted by Karki et al. (2011), intergovernmental organizations like the International Centre for Integrated Mountain Development (ICIMOD) play a pivotal role in building scientific knowledge and capacity by engaging various national, regional, and international actors. A noteworthy cross-country initiative, involving all concerned regional governments, is the establishment of regional flood information system in the Hindu Kush Himalayan Region, for timely exchange of flood data and information for reduction of flood vulnerability in the Ganges-Brahmaputra-Meghna and Indus river basins (ICIMOD 2012). The intergovernmental regional institutions are uniquely placed at the interface of science and policy, and gauging the policy impact of the various programmes can provide vital insights on barriers to policy uptake of research findings.

\section{Discussion}

The need to strengthen adaptation planning and decision making (i.e. governance mechanisms) in Himalayan river basins gets priority in the reviewed literature. The adaptive governance paradigm recommends unambiguous policy purpose, clarity in institutional arrangements and policypractice fit along with stakeholder involvement for successful outcomes (Rijke et al. 2012). From this perspective, the finding of policy ambiguity at national level in Afghanistan, Bhutan, Nepal and Pakistan raises questions about the capacity of the region to operationalize principles of adaptive governance. It is also pertinent to note that the majority of the riparian countries seem to have formulated policy objectives that do not clearly distinguish climate change as an additional stressor to development challenges. On the other hand, capacity building has been integrated into the climate policy objectives of most of the countries.

Our mapping of the institutional landscape points to the need for functional overarching institutional mechanisms at national and regional levels for effectively addressing climate change in a coordinated manner and building technical and institutional capabilities. For example, the absence of a dedicated Ministry of Water Resources in Bhutan seem to have restricted relevant adaptation response in the water sector to project-scale activities without any long-term institutional planning. On the other hand, to overcome the challenge of coordination among multiple agencies, Nepal has formed a Multi-stakeholder Climate Change Initiatives Coordination Committee (MCCICC). India's National Action Plan on Climate Change is steered by the Prime Minister's Council on Climate Change and has prompted similar initiatives at the sub-national level. High-level political commitment helps promote cross-sector policy development (Pittock 2011) and is possibly one of the principal reasons behind its successful diffusion to lower levels of governance.

In the mapping of institutions across countries, a key finding is that there is a common emphasis to strategic knowledge generation to meet climate policy outcomes. Our review suggests that there is a need for integrated assessments factoring social and ecological considerations for adapting to changes in water availability (Pandey et al. 2011; Perveen and James 2011; Viviroli et al. 2011) and studies on the economics of climate change adaptation (Chowdhury and Ward 2007; Osti and Egashira 2009; Attaur and Khan 2011; Tariq and van de Giesen 2012).

Compared to structural measures, non-structural measures such as an effective seasonal climate knowledge base have better feasibility and possibly greater potential to be effective in mitigating the damaging effects of floods. More importantly, such strategic knowledge has applications across sectors and beyond national borders. Chowdhury and Ward (2007), for instance, identify the need for seasonal climate information and forecasts that can feed into current flood preparedness and management measures in Bangladesh. Another example of knowledge based non- 
structural approach to flood management is basin-scale flood risk maps-such GIS-based, interactive maps may utilize historical data analysis as well as modelling approaches and can be linked to an online database and flood warning system (Gaurav et al. 2011).

However, the emphasis over knowledge generation seems to be focussed on political jurisdictions at national level. This ignores the local-level knowledge systems that are recognized as repositories of traditional knowledge and management practices (Kreutzmann 2011; Gain et al. 2012; Manandhar et al. 2012). Similarly, most of the transboundary water sharing agreements in the region are yet to factor in climate change uncertainties (Lebel et al. 2010). Karki et al. (2011) cite that the effectiveness of the Indus Basin Treaty between India and Pakistan, the only transboundary institutional arrangement for Indus Basin water management, has been greatly reduced in a changing climatic scenario. In an extreme scenario, climate changeinduced severe reductions in water flow may result in conflict situation and threaten to undo the existing arrangement based on mutual cooperation. Lebel et al. (2010) opine that, for any new agreement among riparian countries, a preferred alternative would be to promote trust and cooperation by focusing on benefit sharing (considering, for example, power generation benefits, flood control, international trade and food security among others) rather than just physical allocations of water.

Thus, in a river basin context, a scale mismatch between problem and management institutions has major implication for policy. Tucker et al. (2014) cite studies which identify this "disjuncture between policy-making or administrative units compared to the geographically determined unit" in South Asia's river basins. This requires that the traditional fragmented approach to water management has to be replaced by more holistic system view approaches (Gain et al. 2012).

There is an indication of the policy-practice mismatch when one looks at the livelihood-focused adaptation initiatives in the practice domain and contrasts this with the policy emphasis. Out of the total twenty-one adaptation projects reviewed, only three local scale initiatives in two countries-India and Bangladesh-have an explicit focus on livelihood. But, as Ford et al. (2014) cautions, many adaptation actions are undocumented and in many other instances likely to be built into existing mainstreamed programmes to address development priorities. An example of the latter possibility is India's national-level Integrated Watershed Management Programme (IWMP), which has been highlighted as a major adaptation initiative of the Government of India, under which the activities provide sustainable livelihoods to the people residing in watershed areas (MoEF 2012). Similarly, the Mahatma Gandhi National Rural Employment Guarantee Act
(MNREGA), which aims to provide minimum job for 100 days in a year to the adult family members of rural households below poverty line, has been linked to development of land and water resources in villages that would contribute to sustainable and climate-resilient agriculture. It is well acknowledged that effective adaptation interventions require harnessing synergies among various government schemes (Vass et al. 2009; Mirza 2011; Hosterman et al. 2012) along with stakeholder involvement in monitoring and evaluation of policy implementation (e.g. Lebel et al. 2010; MoWR 2012a).

\section{Conclusion}

The study uses the adaptive governance framework to identify three levels-policy, institutions and practicewhich together serve to define the adaptation response in the Himalayan river basins. Apart from India and Bangladesh, there is still ambiguity in goal setting which may constrain policy implementation. At the institutional level, the observation that most of countries are in the process or have already designed structures for knowledge generation and management reflects the capacity for operationalizing the policy mandate of strengthening the scientific base for informed decisions. Thus, a focus on uncertainty reduction for robustness of policy and planning in the South Asia region can be inferred. However, most of the structures maintain the levels of political jurisdiction as their functional scale, which raises a question of fit with the complex issues of climate change that play out in ecological scale. Further, in the practice level, there is a dearth of documentation of initiatives which can specify as adaptation responses. This makes it difficult for evaluation the policy-practice fit, and hence, again questions the capacity to operationalize adaptive governance in the region.

Acknowledgments This work was supported by the CARIAA programme of the International Development Research Centre (IDRC) and the UK Department for International Development (DFID).

Open Access This article is distributed under the terms of the Creative Commons Attribution License which permits any use, distribution, and reproduction in any medium, provided the original author(s) and the source are credited.

\section{References}

Alfieri L, Burek P, Dutra E, Krzeminski B, Muraro D, Thielen J, Pappenberger F (2013) GloFAS: global ensemble stream flow forecasting and flood early warning. Hydrol Earth Syst Sci 17(3):1161-1175 
Atta-ur R, Khan AN (2011) Analysis of flood causes and associated socio-economic damages in the Hindukush region. Nat Hazards 59(3): $1239-1260$

Barua S, van Ast JA (2011) Towards interactive flood management in Dhaka, Bangladesh. Water Policy 13(5):693-716

Berrang-Ford L, Pearce, T, Ford, JD (2014) Systematic review approaches for climate change adaptation research. Reg Environ Change. doi:10.1007/s10113-014-0708-7

Berrang-Ford L, Ford JD, Paterson J (2011) Are we adapting to climate change? Glob Environ Change-Hum Policy Dimens 21(1):25-33

Biesbroek GR, Klostermann JEM, Termeer C, Kabat P (2013) On the nature of barriers to climate change adaptation. Reg Environ Change 13(5):1119-1129

Bocchiola D, Diolaiuti G, Soncini A, Mihalcea C, D'Agata C, Mayer C, Lambrecht A, Rosso R, Smiraglia C (2011) Prediction of future hydrological regimes in poorly gauged high altitude basins: the case study of the upper Indus, Pakistan. Hydrol Earth Syst Sci 15(7):2059-2075

Chaliha S, Sengupta A, Sharma N, Ravindranath NH (2012) Climate variability and farmer's vulnerability in a flood-prone district of Assam. Int J Clim Chang Strateg Manag 4(2):179-200

Chowdhury MR, Ward MN (2007) Seasonal flooding in Bangladesh: variability and predictability. Hydrol Process 21(3):335-347

Cruz RV, Harasawa H, Lal M, Wu S, Anokhin Y, Punsalmaa B, Honda Y, Jafari M, Li C, Huu Ninh N (2007) Asia. Climate change 2007: impacts, adaptation and vulnerability: contribution of working group II to the fourth assessment report of the intergovernmental panel on climate change. In: Parry ML, Canziani OF, Palutikof JP, van der Linden PJ, Hanson CE (eds.), Cambridge University Press, Cambridge

Dahal KR, Hagelman R (2011) People's risk perception of glacial lake outburst flooding: a case of Tsho Rolpa Lake, Nepal. Environ Hazards-Hum Policy Dimens 10(2):154-170

De Souza K, Kituyi E, Leone M, Harvey B, Murali KS, Ford J (2015) Vulnerability to climate change in three hot spots in Africa and Asia: key issues for policy-relevant adaptation and resiliencebuilding research. Reg Environ Change. doi:10.1007/s10113015-0755-8

Folke C, Hahn T, Olsson P, Norberg J (2005) Adaptive governance of social-ecological systems. Annu Rev Environ Resour 30:441-473

Ford JD, Pearce T (2010) What we know, do not know, and need to know about climate change vulnerability in the western Canadian Arctic: a systematic literature review. Environ Res Lett 5 doi:10.1088/1748-9326/5/1/014008

Ford JD, Berrang-Ford L, Bunce A, McKay C, Irwin M, Pearce T (2014) The current status of climate change adaptation policy and practice in Africa and Asia. Reg Environ Change. doi:10. 1007/s10113-014-0648-2

Ford JD, Berrang-Ford L, Paterson J (2011) A systematic review of observed climate change adaptation in developed nations: a letter. Clim Change 106(2):327-336

Fowler HJ, Archer DR (2006) Conflicting signals of climatic change in the Upper Indus Basin. J Clim 19(17):4276-4293

Gain AK, Giupponi C, Renaud FG (2012) Climate change adaptation and vulnerability assessment of water resources systems in developing countries: a generalized framework and a feasibility study in Bangladesh. Water 4(2):345-366

Gaurav K, Sinha R, Panda PK (2011) The Indus flood of 2010 in Pakistan: a perspective analysis using remote sensing data. Nat Hazards 59(3):1815-1826

Government of Bhutan (2011) The water act of Bhutan 2011. www. nec.gov.bt/nec1/wp-content/.../02/Water-Act-FINAL-printed. pdf. Accessed 22 June 2013
Hosterman HR, McCornick PG, Kistin EJ, Sharma B, Bharati L (2012) Freshwater, climate change and adaptation in the Ganges River basin. Water Policy 14(1):67-79

ICIMOD (2012) Establishment of a regional flood information system. http://hydrology.gov.np/new/hydrology/_files/636ff5c5343 a60062d001529ee6c9f15.pdf. Accessed 30 June 2013

Immerzeel WW, van Beek LPH, Konz M, Shrestha AB, Bierkens MFP (2012) Hydrological response to climate change in a glacierized catchment in the Himalayas. Clim Change 110(3-4):721-736

IPCC (2007) Climate change 2007: synthesis report. In: Core writing team, Pachauri RK, Reisinger A (eds.) Contribution of working groups I, II and III to the fourth assessment report of the intergovernmental panel on climate change. IPCC, Geneva, Switzerland

Jain SK, Lohani AK, Singh RD, Chaudhary A, Thakural LN (2012) Glacial lakes and glacial lake outburst flood in a Himalayan basin using remote sensing and GIS. Nat Hazards 62(3): 887-899

Kamal-Heikman S, Derry LA, Stedinger JR, Duncan CC (2007) A simple predictive tool for lower Brahmaputra River basin monsoon flooding. Earth Interact 11:1-11

Karki MB, Shrestha AB, Winiger M (2011) Enhancing knowledge management and adaptation capacity for integrated management of water resources in the Indus River Basin. Mt Res Dev 31(3):242-251

Kreutzmann H (2011) Scarcity within opulence: water management in the Karakoram Mountains revisited. J Mt Sci 8(4):525-534

Lebel L, Xu JC, Bastakoti RC, Lamba A (2010) Pursuits of adaptiveness in the shared rivers of Monsoon Asia. Int Environ Agreem Polit Law Econ 10(4):355-375

Lesnikowski AC, Ford JD, Berrang-Ford L, Paterson JA, Barrera M, Heymann SJ (2011) Adapting to health impacts of climate change: a study of UNFCCC Annex I parties. Environ Res Lett 6 doi:10.1088/1748-9326/6/4/044009

Lesnikowski A, Ford J, Berrang-Ford L, Barrera M, Berry P, Henderson J, Heymann SJ (2013) National-level factors affecting planned, public adaptation to health impacts of climate change. Glob Environ Change 23(5):1153-1163

Manandhar S, Pandey VP, Kazama F (2012) Hydro-climatic trends and people's perceptions: case of Kali Gandaki River Basin, Nepal. Clim Res 54(2):167-179

Mirza MMQ (2011) Climate change, flooding in South Asia and implications. Reg Environ Change 11:S95-S107

MoCC (2012) National climate change policy. Ministry of climate change, Government of Pakistan. Islamabad, Pakistan. http:// www.mocc.gov.pk/gop/index.php?q=aHR0cDovLzE5Mi4xNjgu NzAuMTM2L21vY2xjL3VzZXJmaWxlczEvZmlsZS9Nb2NsYy 9Qb2xpY3kvTmF0aW9uYWwlMjBDbGltYXR1JTIwQ2hhbmdl JTIwUG9saWN5JTIwb2Y1MjBQYWtpc3RhbiUyMCgyKS5w ZGY\%3D. Accessed 15 May 2013

MoE (2010) Climate change vulnerability mapping for Nepal. National adaptation programme of action to climate change. Ministry of Environment, Government of Nepal, Kathmandu, Nepal. http://www.napanepal.gov.np/pdf_reports/CLIMATE\% 20CHANGE\%20VULNERABILITY\%20MAPPING\%20FOR\% 20NEPAL \%20INNER.pdf. Accessed 17 May 2013

MoEF (2009) Bangladesh climate change strategy and action plan 2009. Ministry of Environment and Forests, Government of the People's Republic of Bangladesh, Dhaka, Bangladesh. http:// www.moef.gov.bd/climate_change_strategy2009.pdf. Accessed 27 May 2013

MoEF (2010) Climate change and India: a $4 \times 4$ assessment; A sectoral and regional analysis for 2030s. Ministry of Environment and Forests, Government of India. http://www.moef.nic. 
in/downloads/publicinformation/fin-rpt-incca.pdf. Accessed 23 May 2013

MoEF (2012) India second national communication to the United Nations framework convention on climate change. Ministry of Environment and Forests, Government of India. http://www. moef.nic.in/downloads/publicinformation/India\%20Second\%20 National\%20Communication\%20to\%20UNFCCC.pdf. Accessed 26 May 2013

MoEF (undated) The national Ganga River basin authority programme: an introduction. Ministry of Environment and Forests, Government of India. http://moef.nic.in/sites/default/files/ngrba/ The\%20NGRBA\%20Programme\%20-\%20an\%20intro_2.pdf. Accessed 15 May 2013

Moors EJ, Groot A, Biemans H, van Scheltinga CT, Siderius C, Stoffel M, Huggel C, Wiltshire A, Mathison C, Ridley J, Jacob D, Kumar P, Bhadwal S, Gosain A, Collins DN (2011) Adaptation to changing water resources in the Ganges basin, northern India. Environ Sci Policy 14(7):758-769

MoWR (2012a) Draft national water policy (2012) as recommended by National Water Board in its 14th meeting held on 7th June 2012. Ministry of water resources, Government of India. http:// mowr.gov.in/writereaddata/linkimages/DraftNWP2012_English 9353289094.pdf. Accessed 27 May 2013

MoWR (2012b) Restructuring of Brahmaputra Board. B\&B Division, B\&B Wing, Ministry of Water Resources, Government of India. http://brahmaputraboard.gov.in/NER/Archive/Brahmaputra Board_at_a_Glance.pdf. Accessed 16 may 2013

Mustafa D (2007) Social construction of hydropolitics: the geographical scales of water and security in the Indus Basin. Geogr Rev 97(4):484-501

Nandargi S, Dhar ON (2011) Extreme rainfall events over the Himalayas between 1871 and 2007. Hydrol Sci J J Des Sci Hydrol 56(6):930-945

NEC (2009) Strategizing climate change for Bhutan. National Environment Commission, Royal Government of Bhutan. http:// www.rrcap.ait.asia/nsds/uploadedfiles/file/bhutan.pdf. Accessed 15 May 2013

NEC (2011) Second national communication from the Kingdom of Bhutan to the United Nations framework convention on climate change. National Environment Commission, Royal Government of Bhutan. http://unfecc.int/resource/docs/natc/snc_bhutan.pdf. Accessed 15 May 2013

NEC (undated) Bhutan national adaptation programme of action. National Environment Commission, Royal Government of Bhutan. http://unfccc.int/resource/docs/napa/btn01.pdf Accessed 15 May 2013

NEPA (2009) National capacity needs self-assessment for global environmental management (NCSA) and National Adaptation Programme of Action for Climate Change (NAPA). Final Joint Report. National Environmental Protection Agency, Government of the Islamic Republic of Afghanistan. http://www.unep.org/ dgef/Portals/43/publications/Afghan_NCSA_and_NAPA_2009. pdf. Accessed 5 June 2013

NEPA (2013) Afghanistan Initial National Communication to the United Nations framework convention on climate change. National Environmental Protection Agency, Government of the Islamic Republic of Afghanistan. http://unfccc.int/resource/docs/ natc/afgnc1.pdf. Accessed 5 June 2013

Osti R, Egashira S (2009) Hydrodynamic characteristics of the Tam Pokhari Glacial Lake outburst flood in the Mt. Everest region, Nepal. Hydrol Process 23(20):2943-2955
Pahl-Wostl C (2009) A conceptual framework for analysing adaptive capacity and multi-level learning processes in resource governance regimes. Glob Environ Change 19:354-365

Pandey VP, Babel MS, Shrestha S, Kazama F (2011) A framework to assess adaptive capacity of the water resources system in Nepalese river basins. Ecol Ind 11(2):480-488

Perveen S, James LA (2011) Scale invariance of water stress and scarcity indicators facilitating cross-scale comparisons of water resources vulnerability. Appl Geogr 31(1):321-328

Petticrew M, McCartney G (2011) Using systematic reviews to separate scientific from policy debate relevant to climate change. Am J Prev Med 40(5):576-578

Pittock J (2009) Lessons for climate change adaptation from better management of rivers. Clim Dev 1(3):194-211

Pittock J (2011) National climate change policies and sustainable water management: conflicts and synergies. Ecol Soc 16(2):25. http://www.ecologyandsociety.org/vol16/iss2/art25/

Rijke J, Brown R, Zevenbergen C, Ashley R, Farrelly M, Morisom P, van Herk S (2012) Fit for purpose governance: a framework to make adaptive governance operational. Environ Sci Policy 22:73-84

Rupper S, Schaefer JM, Burgener LK, Koenig LS, Tsering K, Cook ER (2012) Sensitivity and response of Bhutanese glaciers to atmospheric warming. Geophys Res Lett 39:L19503. doi:10. 1029/2012GL053010

Saleth RM (2011) Water scarcity and climatic change in India: the need for water demand and supply management. Hydrol Sci J J Des Sci Hydrol 56(4):671-686

Shah MAR, Douven W, Werner M, Leentvaar J (2012) Flood warning responses of farmer households: a case study in Uria Union in the Brahmaputra flood plain, Bangladesh. J Flood Risk Manag 5(3):258-269

Shahid S (2012) Vulnerability of the power sector of Bangladesh to climate change and extreme weather events. Reg Environ Change 12(3):595-606

Sharma B, Amarasinghe U, Cai XL, de Condappa D, Shah T, Mukherji A, Bharati L, Ambili G, Qureshi A, Pant D, Xenarios S, Singh R, Smakhtin V (2010) The Indus and the Ganges: river basins under extreme pressure. Water Int 35(5):493-521

Tariq M, van de Giesen N (2012) Floods and flood management in Pakistan. Phys Chem Earth 47-48:11-20

Tucker J, Few R, Conway D, Daoud M, Oates N, Mtisi S, Matheson S (2014) Social vulnerability in three high poverty climate change hotspots: what does the climate change literature tell us? Reg Environ Chang. doi:10.1007/s10113-014-0741-6

Vass KK, Das MK, Srivastava PK, Dey S (2009) Assessing the impact of climate change on inland fisheries in River Ganga and its plains in India. Aquat Ecosyst Health Manag 12(2):138-151

Viviroli D, Archer DR, Buytaert W, Fowler HJ, Greenwood GB, Hamlet AF, Huang Y, Koboltschnig G, Litaor MI, LopezMoreno JI, Lorentz S, Schadler B, Schreier H, Schwaiger K, Vuille M, Woods R (2011) Climate change and mountain water resources: overview and recommendations for research, management and policy. Hydrol Earth Syst Sci 15(2):471-504

Xu JC, Grumbine RE, Shrestha A, Eriksson M, Yang XF, Wang Y, Wilkes A (2009) The melting Himalayas: cascading effects of climate change on water, biodiversity, and livelihoods. Conserv Biol 23(3):520-530 